\title{
Evaluation of sensory properties of Kilishi prepared from fermented cattle and camel beef in Semi-arid Nigeria
}

Inusa, S. K. and Muhammad, B. F.

Department of Animal Science, Bayero University, Kano, Nigeria.

Corresponding author: karkarna63@gmail.com; +2347066511904

\section{Abstract}

Meat fermentation is an important processing method with enormous nutritional and health benefits. A study was conducted to examine the sensory properties of fermented cattle and camel beef Kilishi. The effects of meat type, age and packaging on this meat quality attribute were evaluated. The experimental meat samples were fermented before utilized in Kilishi processing. The chunks of meat were sliced and then inoculated with lactic meat starter culture at three concentrations $(2.5,5.0$ and $7.5 \mathrm{~g} / 100 \mathrm{ml} w / \mathrm{v})$. Kilishi samples for the sensory assessment were taken from each product lot. The experiment for the second trial was laid in a $2 \times 3 \times 4$ factorial arrangement in a completely randomized design. The factors are two animal species (cattle and camel) aged 3, 5 and 8 years and above and four packaging arrangements: brown paper $(B)$, polyvinyl chloride $(P)$, aluminium foil and polyvinyl chloride (AP), brown paper and polyvinyl chloride (BP). Data generated were analysed by analysis of variance using SPSS Version 20.0 and GraphPad Instat while significantly different means were separated with Tukey HSD test. The result of sensory evaluation of the experimental Kilishi indicated that colour was ranked high and the product prepared from animals aged 5 years (middle age) and packaged in polyvinyl chloride material was the one preferred. It was concluded that fermentation and packaging improved the sensory quality of the product. Fermentation of cattle and camel beef of animals aged 5 years using 2.5\% meat starter culture and the use of PVC-based package were recommended in semi-arid environment of Nigeria.

Keywords: Meat type, Animal age, Packaging, Meat quality, Meat starter culture.

\section{Évaluation des propriétés sensorielles de Kilishi préparées à partir de bovins} fermentés et de bœuf de chameau dans le Nigéria semi-aride

\section{Résumé}

$\overline{L a}$ fermentation de la viande est une méthode de traitement importante avec d'énormes avantages nutritionnels et de santé. Cette étude a été menée pour examiner les propriétés sensorielles des bovins fermentés et du Kilishi de bovins à base de chameaux. Les effets du type de viande, de l'âge et de l'emballage sur cet attribut de qualité de la viande ont été évalués. Les échantillons de viande expérimentaux étaient fermentés avant l'utilisation de la transformation du Kilishi. Les morceaux de viande ont été tranchés puis inoculés avec une culture de démarreur de la viande lactique à trois concentrations $(2,5,5,0$ et 7,5 g/ $100 \mathrm{ml}$ $w / v)$. Les échantillons de Kilishi pour l'évaluation sensorielle ont été prélevés sur chaque lot de produit. L'expérience du deuxième essai a été déposée dans un arrangement factoriel de 2 $x 3 \times 4$ dans une conception complètement randomisée. Les facteurs sont deux espèces animales (bovins et chameaux) âgés de 3, 5 et 8 ans et plus et quatre arrangements d'emballage: papier brun $(P)$, chlorure de polyvinyle $(C)$, feuille d'aluminium et chlorure de polyvinyle $(F C)$, papier brun et polyvinyle chlorure (PC). Les données générées ont été analysées par analyse de la variance à l'aide de SPSS version 20.0 et du graphique PadinStat, tandis que des moyens nettement différents ont été séparés avec un test de Tukey 
DFS. Le résultat de l'évaluation sensorielle des Kilishi expérimentaux a indiqué que la couleur était élevée et le produit préparé à partir d'animaux âgés de 5 ans (âge moyen) et emballé dans des matériaux de chlorure de polyvinyle était celui préféré. Il a été conclu que la fermentation et l'emballage ont amélioré la qualité sensorielle du produit. Fermentation du bétail et du bouf à base de chameaux d'animaux âgés de 5 ans en utilisant une culture de démarrage de 2,5\% de la viande et l'utilisation de colis à base de PVC ont été recommandées dans un environnement semi-aride du Nigéria.

Mots-clés: Type de viande, Âge d'animal, Emballage, Qualité de la viande, Culture de démarrage à la viande.

\section{Introduction}

According to Hui et al. (2001) meat is the edible postmortem component originating from live animals. The authors further stated that it is the whole or part of the carcass of animals such as buffalo, camel, cattle, goat, pig, poultry, rabbit and sheep slaughtered other than in a wild state, and intended for human consumption. Beef generally refer to the meat of a heifer, cow, bull, young bull, bullock and steer (Emokaro and Amadasun, 2012) and according to Wilson (1984) also camel. Meat can be processed by thermal treatments (smoking, boiling, frying, roasting, drying, cooking, refrigeration and freezing), chemical (fermentation, curing, salting, marination) or mechanical (shredding, mincing, pounding, macerating, canning) techniques. Fermentation in food processing is important in the preservation of foods and has been defined as the conversion of carbohydrates to alcohols, carbon dioxide and organic acids using yeasts, bacteria, and combination thereof, under anaerobic conditions (Hutkins, 2006). Fermented meat products were defined as that inoculated with microorganisms during processing under controlled conditions to give desirable characteristics (Zakpaa et al., 2009). Kilishi, a traditional dried meat product is made from meat infused with spices and defatted groundnut paste (Muhammad and Muhammad, 2007; Abubakar et al., 2011; Olusola et al., 2012) and is produced widely in most northern Nigerian States. The meat from different animal species exhibit varied physicochemical, nutritional and rheological characteristics before and after processing. Similarly, meat produced into Nigerian ready-to-eat snack products such as Tsire, Balangu, Dambun-nama and Kilishi in the semi-arid areas were reported to have varying physicochemical and sensory properties particularly texture, flavour, nutritional value and shelf life (Muhammad et al., 2011). It is assumed that the processing of fermented meat from cattle and camels of different age groups into Kilishi may improve eating quality.

\section{Materials and methods}

The experiment was conducted at the Department of Animal Science, Bayero University Kano. Kano State is located in the semi-arid area of Northwestern Nigeria. It has a hot semi-arid steppe climate which exhibits a tropical wet dry season with a mono modal rainfall distribution. Meat animals, both large (cattle and camels) and small (sheep and goats) are slaughtered daily at various locations in the State including the Kano Main Abattoir and either sold fresh or processed into various readyto-eat snack products such as Tsire, Balangu, Dambun nama and Kilishi. These animals are sourced from local, regional and international markets in Nigeria and neighbouring countries.

Meat handling and processing for fermented Kilishi production 


\section{Inusa and Muhammad}

The conduct of the first experimental study involved the use of raw cattle and camel beef (50 kg each) obtained from the Kano Main abattoir very early in the morning and transported to the Teaching and Research Laboratory of the Department of Animal Science, Bayero University Kano in clean piece of cloth wrapped with brown paper. After deboning, removal of visible fat and connective tissues, the chunks of meat were sliced and then inoculated with Lyocarni' (SACCO Sri Cadorago Co., Italy) dried lactic meat starter culture at three different concentration levels $(2.5,5.0$ and $7.5 \mathrm{~g} / 100$ $\mathrm{ml} / \mathrm{v}$ ).

The meat was thinly sliced to $0.5 \mathrm{~cm}$ thick, 5 $\mathrm{cm}$ wide and $15 \mathrm{~cm}$ length using Vernier caliper for proper inoculation. Meat samples from the semimembranosus muscles of cattle and camel were smeared gently and thoroughly with the solution. The meat was inoculated in $100 \mathrm{ml} / \mathrm{kg}$ and incubated for $4 \mathrm{hrs}$ at $40^{\circ} \mathrm{C}$ (Olaoye and Ntuen, 2011) while the fresh untreated beef and camel meat samples were used as control. For the purpose of the second experiment, raw cattle and camel beef ( 30 $\mathrm{kg}$ each) was obtained and treated as above. The meat samples were obtained from cattle and camels aged 3, 5 and 8 years and above. Animal aging was done by the dentition method according to the procedure described by Ensminger (1992) and Ferguson (1990). The sliced raw beef samples were then inoculated at $2.5 \%$ level of inclusion of LAB meat starter culture as this was found adequate for the fermentation process during the first experiment.

\section{Preparation offermented beef Kilishi}

The fermented cattle and camel beef were prepared into Kilishi according to a modification of the procedure described by Jones et al. (2001). The meat slices were reduced to a moisture content of $40-50 \%$ after a period of 4-5 hours drying. The dried pieces of meat were then soaked in a coating sauce of groundnut cake and condiments (Table 1) for 15 minutes. The soaked meat was removed and spread out again for the second stage drying. The infused meat slices were carefully turned over periodically to avoid sticking to the surface of the drying platform. The drying stages were undertaken under protective cover against dust and flies. After 4 hours of drying, the infused meat slices were roasted for 5 minutes over a glowing smokeless charcoal $\left(80^{\circ}-120^{\circ} \mathrm{C}\right)$ and packaged for analysis (first experiment) or kept for a sixmonth storage period (second experiment).

Table 1: Proportions of ingredients used in the Kilishi coating sauce

\begin{tabular}{|c|c|}
\hline Ingredient & Proportion in Mixture $(\mathrm{g} / \mathrm{Kg})$ \\
\hline Black pepper (Piper guineense) & 15 \\
\hline Clove ( Eugenia caryophyllata) & 10 \\
\hline Alligator pepper (Afromomum meleginata) & 10 \\
\hline Hot pepper (Capsicum frutescens) & 45 \\
\hline Sweet pepper (Capsicum annum) & 50 \\
\hline Onion (Allium cepa) & 130 \\
\hline Ginger (Zingiber officinale) & 25 \\
\hline Garlic (Allium sativa) & 15 \\
\hline African nutmeg (Myristica fragrans) & 5 \\
\hline Seasonings (Maggi ${ }^{\mathrm{R}}$, Thyme $^{\mathrm{R}}$, Curry ${ }^{\mathrm{R}}$ ) & 30,10 and 5 , respectively \\
\hline Decorticated groundnut (Arachis hyphogeaea) & 10 \\
\hline Defatted groundnut cake (Kuli-kuli) & 350 \\
\hline Sugar & 10 \\
\hline Water & 400 \\
\hline Common Salt (Sodium chloride) & 30 \\
\hline
\end{tabular}

Source: Mgbemere et al., 2011; Muhammad et al., 2011; Olusola et al., 2012. 


\section{Experimental lay-out, sampling} procedure and analyses

The experimental lay-out for the first study was a completely randomised design. Samples were also collected for sensory evaluation from each production lot. The experiment for the second trial was laid in a $2 \times 3 \times 4$ factorial arrangement in a completely randomized design. The factors are two animal species (cattle and camel) aged 3, 5 and 8 years and above and four packaging arrangements: brown paper (B), polyvinyl chloride $(\mathrm{P})$, aluminium foil and polyvinyl chloride (AP), brown paper and polyvinyl chloride (BP).

\section{Sensory evaluation of the fermented} cattle and camel beef Kilishi

Samples for sensory evaluation were taken from all the Kilishi lots. A 7-point hedonic scale (Like very much=7; Like moderately $=6$; Like slightly $=5$; Neutral $=4$; Dislike slightly $=3$; Dislike moderately $=2$ and Dislike very much=1) was used for the sensory assessment to score the samples based on colour, flavour, texture, tenderness, aroma, juiciness and overall acceptability (Iwe, 2002; Eke et al., 2013). A 12 member mixed sex semi-trained panel (Watts et al., 1989; Teye and Okutu, 2010) of age range between 25 and 35 years old was requested to assess the blind coded samples of Kilishi. Panelists were given orientation about the sensory parameters evaluated. The evaluation was performed under bright light (Stone and Sidel, 1993; Olusola et al., 2012). Equal bite sizes (7.5 g) from each treatment were blind coded and order of presentation randomized (Watts et al., 1989; Meilgaard et al., 1991).

\section{Statistical analysis}

The data obtained from sensory evaluation were analysed with the GraphPad Instat Statistical package because it is more user friendly to this kind of non-parametric data. Differences among the means of the treatments were separated using Tukey HSD (post hoc) test at 5\% level of probability. The analysis was done using Mann-Whitney and Kruskal-Wallis (Nonparametric ANOVA) Tests. MannWhitney test is the non-parametric equivalent of independent T-test and was used to analyze the data on meat type. Kruskal-Wallis (with Dunn's post hoc) test is the non-parametric equivalent of oneway ANOVA and was used in the analysis of data relating to age group, package materials and storage.

\section{Results}

The effect of meat type on the sensory properties of fermented cattle and camel beef Kilishi is shown in Fig. 1. The result indicated that the colour of the product was rated higher than all the other parameters evaluated. The colour of the fermented Kilishi prepared from camel meat was preferred to that of cattle. The panelists rating of aroma, texture and overall acceptability was virtually the same. The flavour of Kilishi prepared from fermented camel beef was rated higher while that made from cattle beef was preferred more in respect of tenderness.

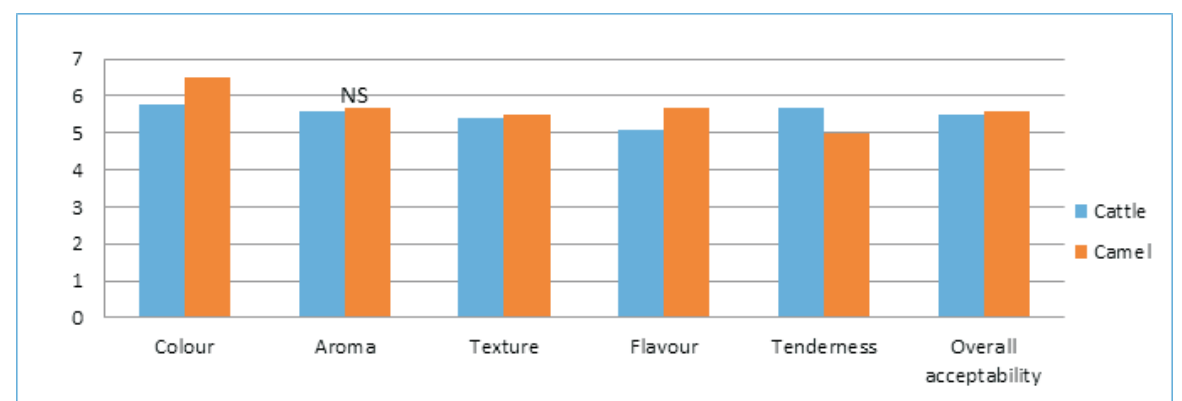

Figure 1. Effect of Meat Type on Sensory Properties of Fermented Cattle and Camel Kilishi. $\mathrm{NS}=$ Not significant. 


\section{Inusa and Muhammad}

The result of fermenting cattle and camel beef with $2.5 \%$ meat starter culture and subsequent processing into Kilishi is presented in Fig. 2. The rating for colour was highest and similar in respect of the two meat types. This inclusion level of meat starter had also similar impact on the texture of the Kilishi. However, the product prepared from cattle beef was preferred more in terms of aroma, flavour and overall acceptability. The tenderness of the Kilishi prepared from camel beef was rated higher.

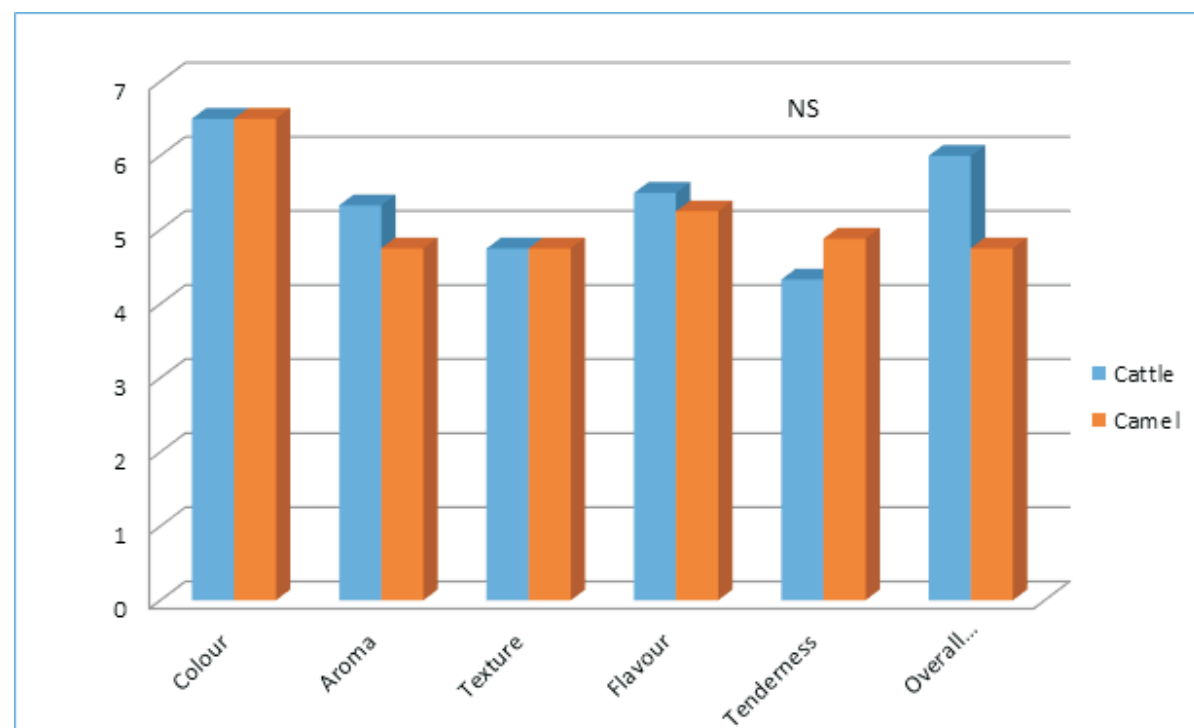

Figure 2. Effect of 2.5\% Meat Starter Concentration on Sensory Properties of Fermented Cattle and Camel Kilishi. Not significant.

The effect of using the LAB meat starter culture at $5 \%$ inclusion rate on the sensory properties of cattle and camel beef Kilishi is shown in Fig. 3. The result indicated that the rating for colour was highest (almost liked very much) for the Kilishi prepared from the two meat types. A slight liking was shown for all the other parameters evaluated. In terms of the rating for aroma, though virtually the same for the experimental Kilishi, that of cattle was slightly preferred. Furthermore, Kilishi prepared from cattle beef was rated higher with respect to texture, flavour, tenderness and overall acceptability.

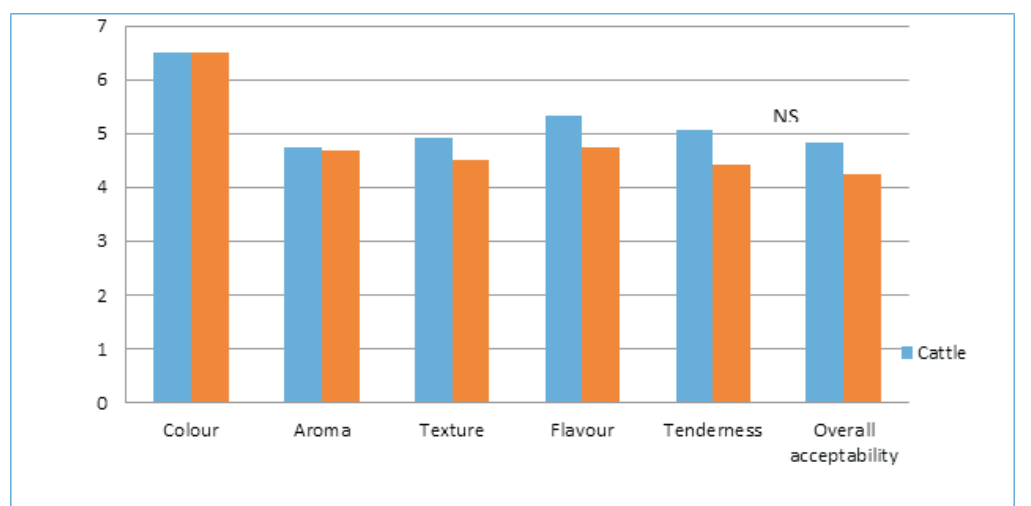

Figure 3. Effect of Using the Meat Starter at 5\% Level of Inclusion on the Sensory Properties of Fermented Cattle and Camel Beef Kilishi. NS= Not Significant. 
The impact of including the meat starter culture at $7.5 \%$ level on the sensory properties of cattle and camel beef Kilishi is shown in Fig. 4. The rating for colour revealed similar trend as in the other levels of inclusion of the meat starter culture because it was very much liked by the panelists irrespective of meat type.
Panelists have also shown slight liking of the product with respect to the other sensory parameters tested. Kilishi produced from cattle beef was preferred in terms of texture and tenderness. The aroma, flavour and overall acceptability of the product prepared from camel beef was however rated higher.

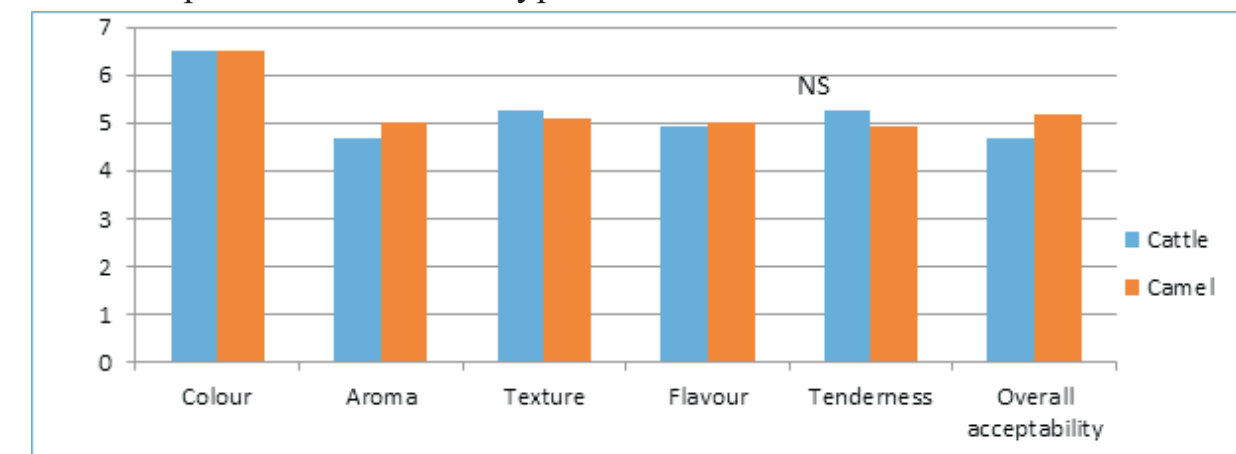

Figure 4. Effect of Using 7.5\% Level of Inclusion of the Meat Starter on the Sensory Properties of Kilishi Prepared from Cattle and Camel Beef. NS= Not significant.

The fermented cattle and camel beef Kilishi prepared for the study was subjected to further sensory assessment. The result in Figure 5 depicts the influence of meat type on the sensory characteristics of the product. Generally, the rating for colour was highest compared to all other parameters. The panelists have shown higher preference for fermented Kilishi prepared from camel with respect to colour, flavour, texture, aroma, juiciness and overall acceptability. Kilishi prepared from cattle meat was rated highest in terms of tenderness.

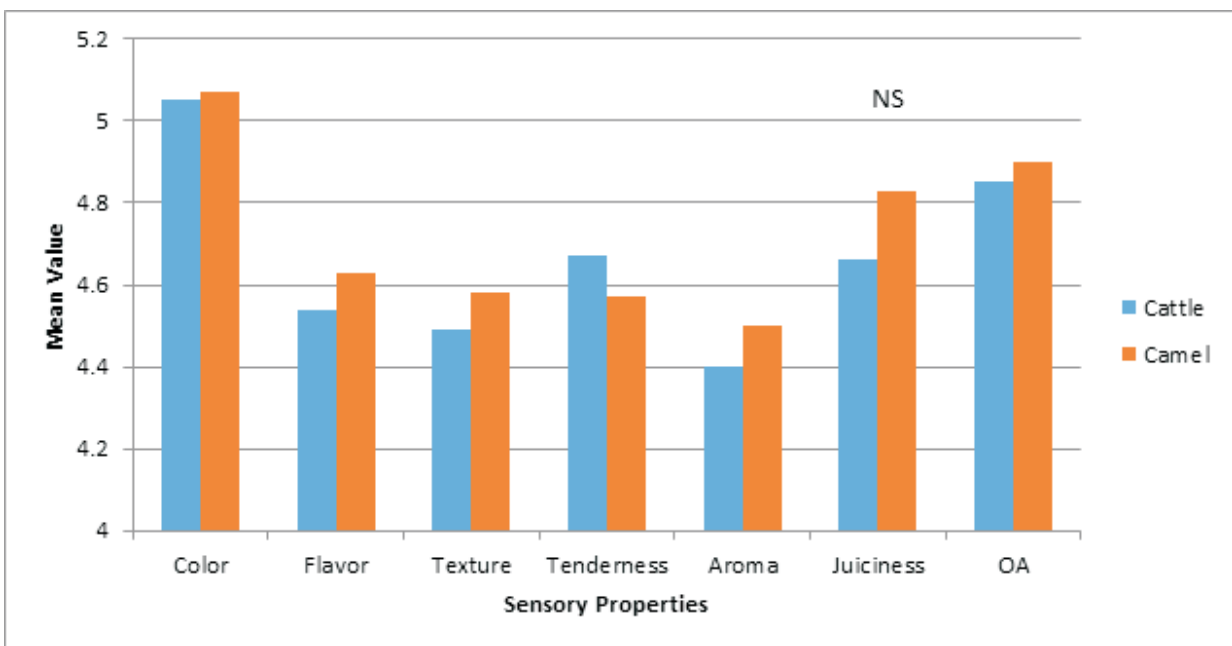

Figure 5. Effect of Meat Type on Sensory Properties of Fermented Kilishi. NS= Not significant 


\section{Inusa and Muhammad}

A graphical presentation of the impact of animal age on the sensory properties of the experimental Kilishi is shown in Figure 6. The rating of the sensory parameters examined indicated that the panelists preferred the fermented cattle and camel Kilishi prepared from animals of the 5 year age category. The product made from animals aged 3 years was rated second with respect to colour and texture. Fermented Kilishi produced from the animals aged 8 years and above was also given the second rank in terms of flavour, aroma and juiciness.

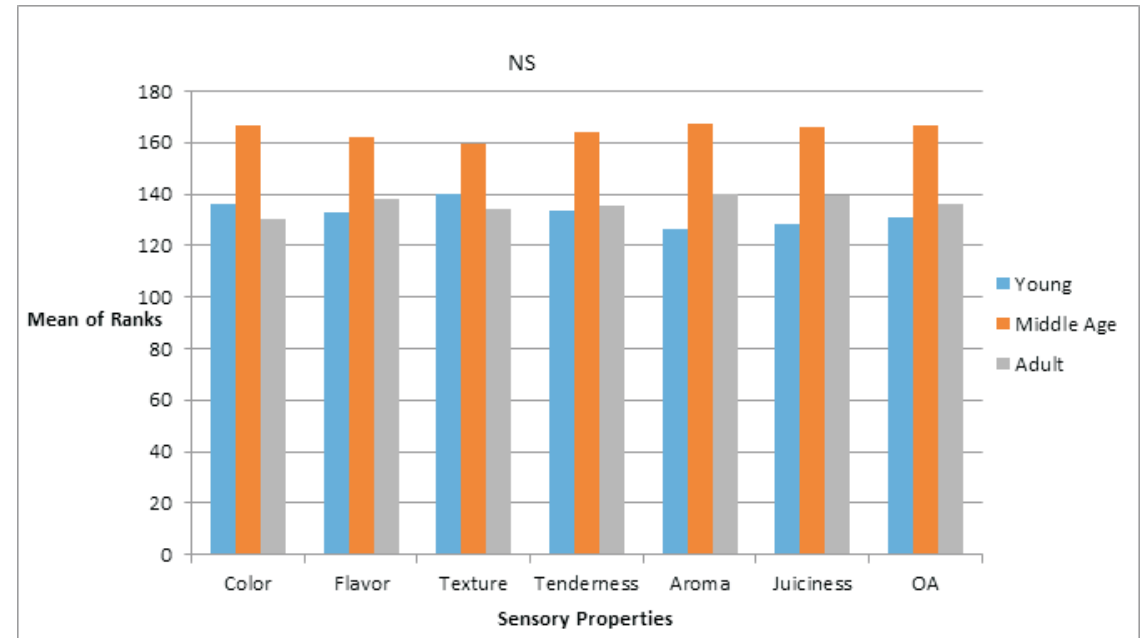

Figure 6. Effect of Age on Sensory Properties of Fermented Kilishi Young=3 years; Middle Age $=5$ years; Adult $=8$ years and above. $N S=$ Not significant .

The result of the panelists rating of the fermented cattle and camel beef Kilishi in respect of using different packaging materials is shown in Figure 7. It was indicated that the rating of the experimental Kilishi samples stored in PVC single layer package was highest. The assessment for colour, flavour, texture, tenderness and overall acceptability was virtually the same in respect of all the packaging media. Kilishi kept in the brown paper single layer package was rated second in terms of aroma and juiciness.

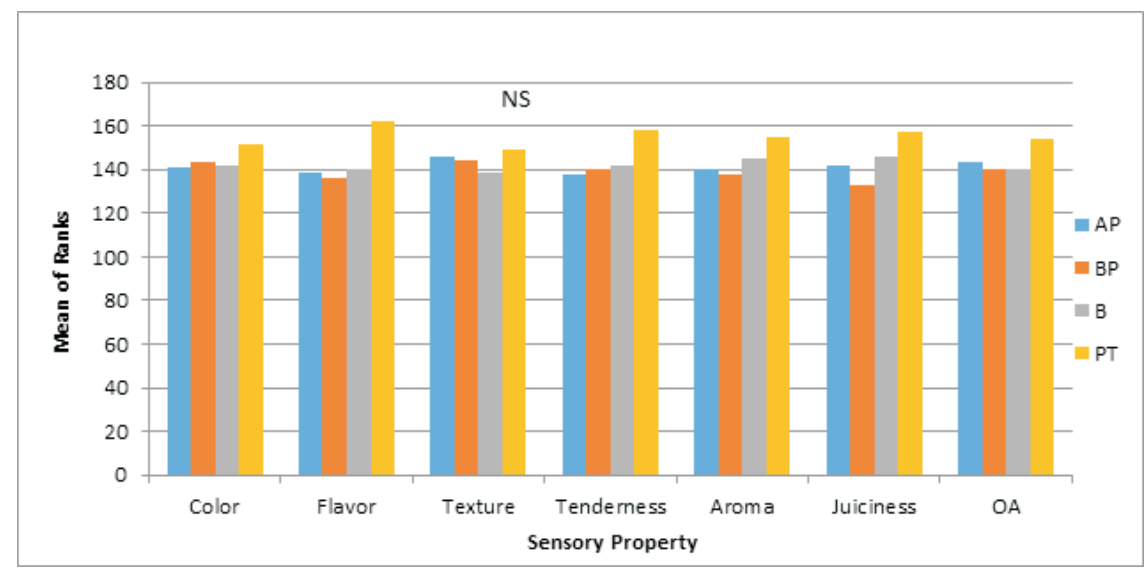

Figure 7. Effect of Packaging on Sensory Properties of Fermented Kilishi AP=Aluminium foil+PVC; BP=Brown Paper+PVC; $B=$ Brown Paper; $P=P V C$. NS= Not significant. 


\section{Discussion}

Sensory evaluation is very important in determining consumer acceptability of meat products. Meat colour is one of the most important sensory characteristics by which consumers make judgements on meat quality. The result of this study has shown that processing of raw cattle and camel beef into Kilishi had changed the colour to dark brown which was more appealing to the people that served as panelists. Kadim et al. (2006) showed that meat from 6-8 and 10-12year old camels was darker (lower L*), redder (higher $a^{*}$ ) and yellower (high $b^{*}$ ) than that from 1-3year old ones because of higher concentrations of myoglobin. This concurred with the findings of the current study. In terms of meat type, colour had the highest ranking in this study. However, a study by Abril et al. (2001) did not detect significant differences in the colour of cooked cattle, camel and goat meat.

Physiologically, the perception of flavour involves the detection of four basic sensations including saltiness, sweetness, sourness and bitterness by the nerve endings of the surface of the tongue (Hedrick et al., 1994). Packaging was found to greatly affect the flavour of the fermented cattle and camel beef Kilishi used in this study. The findings further revealed an influence of meat type on flavour as Kilishi prepared from camel beef was ranked higher than that of cattle.

The tenderness of meat may be defined as the secondary manifestation of the structure of meat and the manner in which this structure reacts to the force applied during biting and the specific senses involved in eating (Moloney, 1999). It was reported that the tenderness of bovine muscle was not affected by increasing animal age (Eskandari et al., 2013). The tenderness of Kilishi samples was reported to be inversely proportional to duration of storage (Iheagwara and Okonkwo, 2016). The finding of the current study indicated that the tenderness of the experimental Kilishi was affected by meat type, age and packaging materials as the products from cattle beef and that prepared from animals (cattle and camels) aged 5 years were more tender in contrast with the report of Eskandari et al. (2013). It was reported that meat toughness increased while palatability decreased with increase in the age of the animal (Suliman, et al., 2012). No tenderness differences were however observed between cattle and camel beef (Kamoun, 1995) of comparable age. Kadim et al. (2006) suggested that young male camel should be slaughtered between 1 and 3 years of age. This was in agreement with the conclusion of Dina and Klintegerg (1977). The experimental fermented Kilishi prepared from cattle in the current study was found to be tenderer than that of camel indicating the effect of meat type on this sensory property.

In a study comparing preference of dried meats from cattle and camel, the former appeared more preferred with respect to flavour, color and overall acceptability (4.8, 4.5 and 4.6 compared with 3.4, 3.5 and 3.1 respectively) among Mongolians (Dorj et al., 2015). No significant differences were recorded on the colour, texture, juiciness, flavour and overall acceptability of Kilishi prepared from cattle and camel beef using different levels of garlic and cinnamon oils (Kazeem et al., 20015). This trend and the magnitude of the preference are in tune with the findings of the current study. Spices contributed greatly to the flavour and acceptability of Kilishi. The blend of these spices with the groundnut paste gave the product a unique pleasant taste and aroma (Olusola et al., 2012). Omojola et al. (2003) reported that one or more spices in Kilishi coating sauce could replace each other without marked differences in flavour, juiciness, pungency, tenderness and overall acceptability. Also, included in Kilishi 


\section{Inusa and Muhammad}

coating sauce are salt, sugar and Maggi which contribute to the desired taste and other sensory properties. Lactic acid bacteria starter culture with probiotic properties had effect on product taste, flavour and aroma as well as positive impact on functional and physiological properties (Palamutoğlu and Kasnak 2014). This was confirmed by the findings of the current study.

Camel meat could be processed in similar ways to beef, giving rise to products with same acceptability (Mansour and Ahmed, 2000). This was in tune with the findings of this study as Kilishi prepared from fermented cattle and camel beef were similarly accepted by the sensory test panelists. Adim et al. (2008) and Williams (2002) reported that camel meat was similar in taste and texture to beef. This was in contrast with the findings of the current study as the ranking of camel beef Kilishi appeared higher. However, camel and cattle beef were found to have more overall acceptability than goat meat (Siham, 2015). The results of the current study had revealed that fermented Kilishi prepared from camel beef was ranked higher for colour and flavour. The same product was also slightly preferred with respect to aroma, texture and overall acceptability.

\section{Conclusion and recommendations}

The findings of this study demonstrated that cattle and camel beef could be used to prepare Kilishi without much difference in sensory properties. It was further concluded that fermentation improved the sensory properties of cattle and camel beef Kilishi. The use of $2.5 \%$ inclusion level of meat starter culture for fermentation was recommended as adequate in producing the desirable sensory qualities in Kilishi. The use of beef from cattle and camel aged 5 years (middle age) was recommended for optimum sensory attributes.
References

Abril, M. M., Campo, A., Onenc, C., Sanudo, P., Alberti, and Negueruela, A. I. 2001. Beef color evolution as a function of ultimate $\mathrm{pH}$, Meat Science 58: 69-78.

Abubakar, M. M., Bube, M. M., Adegbola, T. A., and Oyawoye, E. O., 2011. Assessment of four meat products (Kilishi, tsire, dambu and balangu) in Bauchi metropolis. ACT-Biotechnology Research Communications 1 (1): 40-48.

Adim, I. T., Mahgoub, O., and Purchas, R. W. 2008. A review of the growth, and of the carcass and meat quality characteristics of the onehumped camel (Camelus dromedaries). Meat Science. 80 (3):555-569.

Dina, D., and Klintegerg, R., 1977. Proposal for a rural development training project and study concerned lands in Ethiopia. Mimeo. Addis Ababa Relief and Rehabilitation Commission. II pp.

Dorj, S., Tsagaan, A., and Sekikawa, M. 2015. Quality of Dried Meats from Different Livestock Species, Journal of agricultural sciences 15 (02): 3-9.

Eke, M. O., Ariahu, C. C., and Abu, J. O. 2013. Sensory and Chemical Evaluation of Beef Based Dambunama (BBDN). Advanced Journal of Food Science and Technology, 5 (10): 1271-1274.

Emokaro, C.O., and Amadasun, O.J. 2012. Analysis of Beef Marketing in Benin City, Nigerian Journal of Agriculture, Food and Environment, 8 (3): 26-31.

Ensminger, M.E., 1992. The Stockman's Handbook, 7th ed. Interstate Publishers, Inc.

Eskandari, M. H., Majlesi, M., Gheisari, H. R., Farahnaky, A., and 
Khaksar, Z. 2013. Comparison of some physicochemical properties and toughness of camel meat and beef. Journal of Applied Animal Research, 41:4, 442-447.

Ferguson, M. 1990. The Dentition throughout Life. In: The Dentition and Dental Care, Vol. 3, R.J. Elderton (Ed.), Oxford Heinemann Medical Books, Oxford, pp. 1-18.

Hedrick, H. B., Aberle, E. D., Forrest, J. C. Judge, M. D., and Merkel, R. A. 1994. Properties of Fresh Meat. In: Hedrick H.B, Aberle E.D, Forrest J.C, Judge M.D, Merkel R.A (Eds). Principle of Meat Science. Dubuque, A.I. Kendall/Hunt Publishing Company.pp.123-131.

Hui, Y. H., Nip, W. K., Rogers R. W., and Young, O. A. 2001. Meat Science and Applications. Marcel Dekker, Inc. New York. p. 674.

Hutkins, R. W., 2006. Meat fermentation. In Hutkins, R. W. (ed.). Microbiology and technology of fermented foods, Blackwell Publishing. pp. 207-232.

Iheagwara, M. C. and Okonkwo, T. M. 2016. Effect of Processing Techniques on the Microbiological Quality of Kilishi - A Traditional Nigerian Dried Beef Product. Journal of Meat Science and Technology, 4(1):11-17.

Iwe, M. O., 2002. Hand Book of Sensory Methods and Analysis. Rojoint Communication Services Ltd., Enugu, Nigeria. pp 56-77.

Jones, M. J., Tanya, V. N., Mbofung, C. M. F., Fonkem, D. N., and Silverside, D. E., 2001. A microbiological and nutritional evaluation of the West African dried meat product, Kilishi. Journal of Food Technology in Africa, 6 (4): $126-129$.
Kadim, I. T., Mahgoub, O., Al-Marzoogi, W., Al-Zadjali, S., Annamalai, K. and Mansour, M. H., 2006. Effects of age on composition and quality of muscle longissimus thoracis of the Omani Arabian camel (Camelus dromedaries). Meat Science, 73: 619 - 625.

Kazeem S. A., Muhammad B. F. and M i c h a e l V. A. 2015 . Environmental Concern on the Use of Natural Oils on Sensory Evaluation of Stored Beef and Camel Meat Kilishi. Open Journal of Applied and Theoretical Environmental Sciences, 1 (1): 2030.

Mansour, M. E., and Ahmed, S. M., 2000. Advanced technology in camel meat processing. The Camel Newsletter, 17: 27-29.

Meilgaard, M., Civille, G. V. and Carr, B. T. 1991. Sensory Evaluation Techniques. Vol. 3. CRC Press Inc., Boca Raton, FL. pp. 23-56.

Mgbemere, V. N., Akpapunam, M.A. and Igene, J. O. 2011. Effect of Groundnut Flour Substitution on Yield, Quality and Storage Stability of Kilishi - A Nigerian Indigenous Dried Meat Product. African Journal of Food, Agriculture, Nutrition and Development, 11 (2): 4718-4738.

Moloney. A. 1999. The quality of meat from Beef cattle-is it influenced by diet? In $\mathrm{R}$ and Hall Technical Bulletin Issue No 4.

Muhammad, B. F., Mahmud, A. B. and Mustapha, A. 2011. Effect of Processing Method on Composition and Acceptability of Camel (Camelus dromedarius) Meat and Beef. Nigerian Journal of Animal Production, 38 (1): 135144.

Muhammad, B. F. and Muhammad, A. 
M. 2007. Effects of Packaging Material and Storage Period on Microbial Load and Organoleptic Properties of Kilishi. Tropical Journal of Animal Science, 10 (12): 217-220.

Olaoye, O. A. and Ntuen, I. G. 2011. Spoilage and preservation of meat: a general appraisal and potential of lactic acid bacteria as biological preservatives. International Research Journal of Biotechnology, 2(1):033-046.

Olusola, O. O., Okubanjo, A. O. and Omojola, A. B. 2012. Nutritive and Organoleptic Characteristics of Kilishi as Affected by Meat Type and Ingredient Formulation. Journal of Animal Production Advances, 2(5): 221-232.

Omojola, A. B., Isah, O. A., Adewunmi, M. K., Ogunsola, O. O. and Attah, S. 2003. Evaluation of the Effects of Various Additives on the Acceptability of Kilishi. Tropical Journal of Animal Science, 6 (2): 97-101.

Palamutoğlu, R. and Kasnak, C. 2014. Use of Probiotics in Fermented Meat Products. Turkish Journal of Agriculture, Food Science and Technology, 2 (5): 208-213.

Siham A. A. 2015. Sensory Evaluation of Different Types of Red meat in Sudan. Bulletin of Environment, Pharmacology and Life Sciences, 4 (11): 45-48.
Stone, H. and Sidel, J. L. 1993. Sensory Evaluation Practices. 2nd ed. Academic Press, Inc. New York, NY.pp. 67-79.

Sulieman, A. M. E., Abdelhai, M. H. and Babiker, E. B. 2012. Some Chemical and Microbiological Characteristics of Agashi Meat Product, Food and Nutrition Sciences, 3: 851-856.

Teye, G. A. and Okutu, I. 2010. Effect of Ageing under Tropical Conditions on the Eating Qualities of Beef. African Journal of Food, Agriculture, Nutrition and Development, 9 (9): 1901-1913.

Watts, B. M., Ylimaki, G. L., Jeffery, L. E. and Elias, L. G. 1989. Basic Sensory Methods for Food Evaluation, International Development Research Centre, Ontario, Canada. p. 163.

Wilson, R., T., 1984. The Camel. London: Longman Group Ltd. pp. 83-101.

Zakpaa, H. D., Imbeah, C. M. and MakMensah, E. E. 2009. Microbial characterization of fermented meat products on some selected markets in the Kumasi metropolis, Ghana. African Journal of Food Science, 3(11): 340-346.

Received: $10^{\text {th }}$ February, 2021 Accepted: $15^{\text {th }}$ August, 2021 


\section{Physicochemical and sensory characteristics of soft cheese as affected by different salt levels \\ ${ }^{2}$ Koranteng, B. A., ${ }^{* 1}$ Awodoyin O.R., ${ }^{1}$ Adediran, A. O. and ${ }^{1}$ Omojola A. B. \\ * Animal Products and Processing Unit, Department of Animal Science, University of Ibadan \\ *2 College of Agriculture and Natural Resources, Department of Animal Sciences,} Kwame Nkrumah University of Science and Technology, Ghana Corresponding author: kasyem@yahoo.com; +2348027290842

Abstract

Cheese, a nutrient-dense dairy food is very rich in protein and calcium. Salting during cheese production is an important step because its concentration is the major factor that influences the organoleptic quality especially flavour. In order to accommodate increasing demands for reduced-sodium cheese without compromising palatability and safety, it is therefore imperative to assess the effect of different salt levels that will produce good quality cheese. Raw milk was obtained from Gudali, Mali and Burkina cows at the Cattle and Dairy Research Station-Bodi, Ashanti, Ghana. There were five treatments and each consists of 1000 $m L$ of milk, $2.5 \mathrm{~mL}$ of juice from Calotropis procera as coagulant and graded levels of salt (0, $4,8,12,16 \mathrm{~g})$. Cheese was produced using standard procedure. Yield (\%), proximate composition (\%) mineral contents (sodium, chlorine, calcium, phosphorus) and texture profile analysis (adhesiveness, chewiness, cohesiveness elasticity, firmness, gumminess resilience was assessed on freshly prepared cheese. The result revealed that cheese $p H$ slightly increased as salt concentration increased. The moisture of $T_{2}(59.47)$ and $T_{3}(58.70)$ were not significantly $(P>0.05)$ different but these were different from $T_{1}(54.67), T_{4}(56.60)$, $T_{5}(50.37)$. The crude protein contents of $T_{3}(16.36)$ and $T_{1}(15.68)$ were significantly higher $(P<0.05)$ than $T_{2}(13.90), T_{4}(10.77)$ and $T_{5}(10.32)$. The fat contents of $T_{4}(14.41)$ and $T_{5}$ (17.28) were significantly higher $(P<0.05)$ compared with others. The yield (33.64) and calcium content (1.49) of $T_{3}$ and phosphorus content (2.35) of $T_{5}$ were significantly higher $(P<0.05)$ than others. The texture profile analysis indicated that the adhesiveness, cohesiveness and resilience of cheese $T_{4}$ and $T_{5}$ were significantly lower $(P<0.05)$; while the chewiness, elasticity, firmness and gumminess of $T_{4}$ and $T_{5}$ were significantly higher $(P<0.05)$. The study revealed that cheese with salt inclusion level of $8 g\left(T_{3}\right)$ possesses the characteristics of a good quality cheese.

Keywords: Cheese, concentration, sodium chloride, yield, texture profile

\section{Caractéristiques physicochimiques et sensorielles du fromage à pâte molle telles qu'affectées par différents niveaux de sel}

\section{Résumé}

Le fromage, un aliment laitier riche en nutriments, est très riche en protéines et en calcium. Le salage lors de la fabrication du fromage est une étape importante car sa concentration est le facteur majeur qui influence la qualité organoleptique en particulier la saveur. Afin de répondre à la demande croissante de fromages à faible teneur en sodium sans compromettre l'appétence et la sécurité, il est donc impératif d'évaluer l'effet des différents niveaux de sel qui produiront un fromage de bonne qualité. Le lait cru a été obtenu à partir de vaches Gudali, Mali et Burkina à la Bovin et Station de recherche laitière-Bodi, Ashanti, Ghana. Il y 


\section{Quality evaluation of soft cheese as affected by graded levels of salt}

avait cinq traitements et chacun se compose de $1000 \mathrm{ml}$ de lait, 2,5 $\mathrm{ml}$ de jus de Calotropisprocera comme coagulant et des niveaux gradués de sel (0, 4, 8, 12, 16 g). Le fromage a été produit en utilisant une procédure standard. L'analyse du rendement (\%), de la composition approximative (\%) des teneurs en minéraux (sodium, chlore, calcium, phosphore) et du profil de texture (adhésivité, mastication, cohésion, élasticité, fermeté, résistance à la gomme a été évaluée sur du fromage fraîchement préparé. Le résultat a révélé que le $\mathrm{pH}$ du fromage légèrement augmenté avec l'augmentation de la concentration en sel. $L$ 'humidité de T2 $(59,47)$ et T3 $(58,70)$ n'étaient pas significativement différentes $(P>0,05)$ mais elles étaient différentes de T1 (54,67), T4 (56,60), T5 (50,37). les teneurs en protéines de $T 3(16,36)$ et $T 1(15,68)$ étaient significativement plus élevées $(P<0,05)$ que celles de T2 (13,90), T4 $(10,77)$ et T5 $(10,32)$ Les teneurs en graisses de T4 $(14,41)$ et T5 $(17,28)$ étaient significativement plus élevé $(P<0,05)$ par rapport aux autres. Le rendement $(33,64)$ et la teneur en calcium $(1,49)$ de T3 et la teneur en phosphore (2,35) de T5 étaient significativement plus élevés $(P<0,05)$ que les autres. L'analyse du profil de texture a indiqué que le l'adhésivité, la cohésion et la résilience des fromages T4 et T5 étaient significativement plus faibles $(P<0,05)$; tandis que la mastication, l'élasticité, la fermeté et la gomme des T4 et T5 étaient significativement plus élevées $(P<0,05)$. L'étude a révélé que le fromage avec un taux d'inclusion de sel de $8 g$ (T3) possède les caractéristiques d'un fromage de bonne qualité. Mots-clés : Fromage, concentration, chlorure de sodium, rendement, profil de texture

\section{Introduction}

Cheese is a nutrient-dense dairy food that is rich in protein, calcium and offers consumer large diversity in flavour, texture, appearance, cooking properties and usage applications (McCarthy et al., 2015). Salting is an important step in cheese and traditionally common (sodium chloride) is the main source in cheese (El-Bakry, 2012). Salt in cheese is of utmost importance to microbial and enzyme activities and directly contributes to organoleptic quality especially flavour (Habib, 2015). It imparts saltiness, enhances mouth-feel and balancing while suppressing off-flavours (bitterness) thus the overall palatability of cheese (Breslin and Beauchamp, 1997). However, its concentration is one of the most important factors influencing the overall quality of cheese (Guo et al., 1997; Paulson et al., 1998). This is because texture development, casein hydration and conformation during cheese production behave in a concentration-dependent manner (Guinee and Fox, 2004). Therefore, in order to accommodate increasing demands for cheese with reduced sodium without compromising safety and palatability, it is imperative to assess the effect of different salt levels that will produce cheese of good quality. In this study, cheese trial was designed to investigate the isolated effect of salt $(\mathrm{NaCl})$ on yield and nutrient composition of soft cheese made from cow milk using coagulants of plant origin Calotropis procera (Sodom apple).

\section{Materials and methods Sample collection}

The raw cow milk for the cheese production was obtained from three dairy animals Gudali, Mali and Burkina cows at the Cattle and Dairy Research Station-Bodi in the Ashanti region of Ghana republic.

\section{Milk collection}

The environment and the milking parlour were thoroughly cleaned prior to milking. The animals were hand milked into plastic buckets and immediately clarified into sterilized screw capped bottles by the use of net sieve and cheese cloth to remove any dirts/ debris/sediments. The appearance and temperature (using a thermometer) of the 